\title{
EFFECTS OF CADMIUM AND ZINC ON STEROID METABOLISM AND STEROID LEVEL IN THE SEA STAR ASTERIAS RUBENS L.
}

\author{
P. A. Voogt, P. J. den Besten, G. C. M. Kusters and M. W. J. Messing \\ Research Group for Invertebrate Reproductive Physiology, Laboratory of Chemical Animal Physiology, \\ State University of Utrecht, 8 Padualaan, Utrecht, The Netherlands
}

(Received 15 April 1986)

\begin{abstract}
Steroid metabolism was studied in gonads and pyloric caeca of male and female sea stars which had been exposed to cadmium or zinc for 3 weeks.

2. Steroid metabolism had increased in animals exposed to heavy metals. Significant increase of the enzyme activity was observed for $17 \alpha$-hydroxylase in the pyloric caeca of female animals exposed to zine (pregnenolone $\rightarrow 17 \alpha$-hydroxypregnenolone) or cadmium (progesterone $\rightarrow 17 \alpha$-hydroxyprogesterone), for $17 \beta$-hydroxysteroiddehydrogenase in the gonads of female animals (dehydroepiandrosterone $\rightarrow$ androstenediol) and in pyloric caeca of male animals (androstenedione $\rightarrow$ testosterone) after exposure to cadmium, and for $5 \alpha$-reductase (progesterone $\rightarrow 5 \alpha$-pregnane-3,20-dione) in ovaries of cadmium exposed sea star.

3. There is some evidence that pregnenolone metabolism in male and female animals is affected by zinc in a different way. The effect of cadmium on the esterification of androstenedione differed highly significantly among male and female animals.

4. It was concluded that the main way of entrance of cadmium into sea stars is via the surrounding medium and not via the food consumed.

5. Testosterone and progesterone levels in, respectively, gonads of female and pyloric caeca of male sea stars which had been exposed to cadmium were significantly higher than the corresponding values in control animals.

6. The effect of zinc exposure on testosterone level in pyloric caeca is significantly different for both sexes.

7. Cadmium interacts directly with the esterification of testosterone, strongly stimulating this process. Cadmium stimulates the production of testosterone by action at the level of the biosynthesis of $17 \beta$-hydroxysteroiddehydrogenase.
\end{abstract}

\section{INTRODUCTION}

The toxic effects of heavy metals at high doses have been known already for centurics (Needleman, 1980). Therefore, $\mathrm{LC}_{50}$ and $\mathrm{LD}_{50}$ values have been determined for most of them.

In the last decade(s), there has been an increasing interest in the sublethal effects of these metals, which might affect the reproductive capacity and thus interfere with the population maintenance of animal species.

In general, little is known about the mechanism of action or the point of attack of the heavy metals in the reproduction process. Recently, Wiebe et al. (1983) showed that lead, which strongly depresses the onset of gamete production in the testes of rat, also depresses the gonadotropin-receptor binding and steroidogenesis in these organs. The reduced $\mathrm{FSH}-$ receptor binding resulted in a decreased hormoneinduced cyclic AMP production and progesterone metabolism. They also showed a direct inhibitory effect of lead on the enzyme $3 \beta$-hydroxysteroiddehydrogenase ( $3 \beta$-HSD), the key enzyme in steroid metabolism

The harmful effects of cadmium on spermatogenesis in rats are well known (Parizek and Zahor, 1956) and have been confirmed since then for several scrotal mammals. The picture is less clear for non-scrotal animals. The deleterious cffect of cadmium in the testes of birds is well documented (Mackawa et al., 1964; Sarkar and Mondal, 1973), but cadmium did not cause testicular degeneration in frogs (Chiquoine, 1964). On the other hand, Biswas et al. (1976) showed an inhibitory effect of cadmium on spcrmatogenesis in the toad and mentioned (unpublished results) an increase in the activity of $3 \beta$-HSD in testes, while Ghosh et al. (1984) reported a decreased $17 \beta$-IISD activity in toad testes after cadmium administration. In the Bidder's organ (a rudimentary ovary) of male toads, the activity of $3 \beta$-HSD and $17 \beta$-HSD increased after treatment with cadmium (Ghosh et al., 1984).

The data reviewed suggest that the deleterious effects of heavy metals on reproduction may result from the interference of these metals with steroidogenesis.

Particularly in aquatic ecosystems, the toxic effects of heavy metals may be evident since the animals are completely submersed in and surrounded by the pollutant and cannot avoid the eventual harmful effects.

Jangoux and Vloebergh (1973) studied the sea star population near Knokke at the Belgian coast and found that it was characterized by animals of a small size and a high degree of oocyte degeneration. They suggested that the small size of the animals and the 
marked degree of sterility may be due to pollution via the Scheldt.

Since reproduction of sea stars is regulated by steroids (Voogt et al., 1984), it is obvious to hypothesize that the eventual effects of pollution mentioned above may be achieved by interference of pollutants with steroid metabolism. As the pollution at Knokke is undefined and the pollutants may be very diverse, we focused our attention on heavy metals and conducted an experiment in which the effect of cadmium and zine exposure on steroid metabolism and steroid level in the sea star Asterias rubens was studied.

\section{MATERIALS AND METHODS}

\section{Animals}

Sea stars, Asterias rubens, were collected from the Wadden Sea (The Netherlands) in June and October 1984 and maintained in the laboratory in running sea-water at a temperature of $12^{\circ} \mathrm{C}$ at natural daylength and fed al libitum with the sea mussel Mytilus edulis.

In the first experiment, conducted in the middle of September, three groups of ten animals were placed in separate aquaria containing $30 \mathrm{l}$. of aerated sea-water. One group was exposed to $100 \mathrm{ppb} \mathrm{Cd}\left(\mathrm{CdCl}_{2}\right)$, a second to $240 \mathrm{ppb} \mathrm{Zn}\left(\mathrm{ZnCl}_{2}\right)$, and the third group served as a control. The water was replaced daily.

The second experiment was conducted in the beginning of November and comprised two groups of ten animals. One group was exposed to $100 \mathrm{ppb} \mathrm{Cd}$ and the other served as the control. The water was replaced each second day, Further conditions were the same as in experiment 1. Exposure lasted for 21 days in both experiments.

\section{Chemicals}

$7(n){ }^{3} \mathrm{H}$-pregnenolone* (specific activity $777 \mathrm{GBq}$ ) mmole), $7(n){ }^{3}$ H-dehydroepiandrosterone* (specific activity $851 \mathrm{GBq} /$ mmole), 1,2,6,7-3 $\mathrm{H}$-progesterone* (specific activity $3.44 \mathrm{TBq} /$ mmole) and $1,2,6,7{ }^{3} \mathrm{H}$-androstenedione* (specific activity $3.65 \mathrm{TBq} / \mathrm{mmole}$ ) were purchased from Amersham International (Amersham, UK) and were purified before use by thin-layer chromatography. Steroids were from Steraloids Incorporation (Pawling, USA) and Sigma Chem ical Corporation (St Louis, USA). NADPH was obtained from Boehringer (Mannheim, W. Germany), and all other chemicals and organic solvents (analytical reagent grade) from Baker Chemicals (Deventer, The Netherlands).

\section{Dissection of the animals}

After the exposure, the animals were dissected in the usual way and the gonads and pyloric caeca were taken out. Sex was determined by microscopical examination of a squash preparation of the gonads.

Pieces of the gonads and pyloric caeca were frozen in

*Steroid nomenclatute: Pregnenolone: $3 \beta$-hydroxypregn5-en-20-one. 17\%-Hydroxypregnenolone: $3 \beta, 17 \alpha-$ dihydroxypregn-5-en-20-one. Pregnanedione: $5 \alpha$-pregnane-3,20-dione. Progesterone: pregn-4-ene-3,20-dione. $17 \alpha-$ Hydroxyprogesterone: $3 \beta, 17 \alpha$-dihydroxypregn-4-en20-one. Dehydroepiandrosterone: $3 \beta$-hydroxyandrost 5-en-17-one. Androstenediol: $3 \beta, 17 \beta$-dihydroxyandrost5-ene. Androstenedione: androst-4-ene-3,17-dione. Androstanedione: $5 \alpha$-androstane-3,17-dione. Testosterone: $17 \beta$-hydroxyandrost-4-en-3-one. Oestrone: 3-bydroxyoestra-1,3,5(10)-trien-17-one. Oestradiol-178: 3,176-dihydroxyoestra-1,3,5(10)-triene. liquid nitrogen and stored at $-20^{\circ} \mathrm{C}$ for estimation of steroid levels.

\section{Incubations}

Pieces of ovary $(0.1 \mathrm{~g}$ in experiment $\mathrm{I}$ and $0.3 \mathrm{~g}$ in experiment II) and pyloric caeca ( $0.5 \mathrm{~g}$ in both experiments) were incubated in a medium consisting of $0.2 \mathrm{ml}$ propyleneglycol containing $37 \mathrm{kBq}(1 \mu \mathrm{Ci})$ of one of the radioactive steroids (pregnenolone, dehydroepiandrosterone, progesterone or androstenedione), and $2 \mathrm{ml}$ of a phosphate buffer ( $\mathrm{pH} 7.4 ; 0.1 \mathrm{M}$ ) containing $0.25 \mathrm{M}$ sucrose.

Incubations were performed under continuous shaking at $17^{\circ} \mathrm{C}$ in an air atmosphere. Incubation times were different for gonad and pyloric caeca tissue and for most steroid precursors. For pregnenolone and dehydroepiandrosterone these times were 2.5 and $2 \mathrm{hr}$ for gonad and pyloric caeca, respectively. The corresponding times were 45 and $30 \mathrm{~min}$ for progesterone, and 30 and $20 \mathrm{~min}$ for androstenedione.

The incubations were terminated by addition of $4 \mathrm{ml}$ dichloromethane.

In experiment III, incubations were performed with both pieces and a homogenate of the pyloric caeca of a male sea star, which had not been exposed to cadmium. Pyloric caeca tissue was homogenized with a Potter-Elvehjem homogenizer at $0^{\circ} \mathrm{C}$ in phosphate buffer $(\mathrm{w} / \mathrm{v}, 1: 3)$. The homogenate was centrifuged for $10 \mathrm{~min}$ at $600 \mathrm{~g}$ and $4^{\circ} \mathrm{C}$ and the supernatant was used further. The incubation medium consisted of $0.2 \mathrm{ml}$ propyleneglycol containing $15 \mathrm{kBq}$ $(0.4 \mu \mathrm{Ci})$ of ${ }^{3} \mathrm{H}$-androstenedione, $0.5 \mathrm{ml}$ of phosphate buffer or $0.5 \mathrm{ml}$ of this buffer with $600 \mathrm{ppb} \mathrm{Cd}^{2+}$ (final concentration $100 \mathrm{ppb}$ ), and in the case of the homogenates $0.3 \mathrm{ml}$ of phosphate buffer containing NADPH (final concentration $2 \mathrm{mM}$ ). All incubations were carried out five times. They were started by adding to the medium either $0.4 \mathrm{~g}$ caeca tissue and $1.9 \mathrm{ml}$ phosphate buffer or $2.0 \mathrm{ml}$ of the caeca homogenate. The further procedure was as described for experiments I and II.

\section{Extraction}

The tissue was homogenized by sonification $\left(\mathrm{B}_{12}\right.$ Sonifier, Branson Sonic Power Company, Danbury, USA) and then extracted with dichloromethane $(3 \times 2 \mathrm{ml})$. In experiment $I$, $50 \mathrm{Hg}$ of the sternids which thenretirally can be formed from the precursors in two reaction steps were added before homogenization.

Thin-layer chromatography (TLC)

Samples were subjected to TLC on Silicagel precoated plates (Merck, DC-Fertigplatten $60 \mathrm{~F} 254$ ).

The following solvent systems were used: (A) for general purposes:

1. Dichloromethane-methanol (97:3), once developed, to purify the radinactive precursors.

2. Toluene-cyclohexane $(1: 1)$, twice developed, to remove excess of fatty materials.

(B) For separation of metabolites formed:

3. Benzene-ethylacetate $(3: 1)$, thrice developed, after incubations with pregnenolone or progesterone.

4. Chloroform -thanol $(9: 1$ or $19: 1)$, once developed after incubations with dehydroepiandrosterone.

5. Disopropylether-chloroform-hexane $(7: 2: 1)$, thrice developed, after incubations with androstenedione.

(C) For further identification of individual components:

6. Benzene ethanol $(9: 1)$, once developed

7. Cyclohexane-ethylacetate $(1: 1)$, once developed

8. Cyclohexane-ethylacetate-ethanol $(9: 9: 2)$, once developed.

Steroids were visualized by u.v. light at $254 \mathrm{~nm}$, or after spraying with a primuline solution at $366 \mathrm{~nm}$ (Wright, 1971).

After steroid detection and location marking, plates were sprayed with a saturated solution of vitamin $C$ in ethanol to prevent oxidation of steroids. 


\section{Acetylation and saponification}

Acetylation of steroids and alkaline hydrolysis of steroid esters were performed as described previously (Voogt and Van Rheenen, 1986).

\section{Purification and identification of steroids}

This was performed by means of TLC using several solvent systems and comparing the $R f$-values with those of reference and carrier steroids. Finally, radioactive steroids were recrystallized, after addition of $10 \mathrm{mg}$ of the presumed steroid, to constant specific radioactivity using aqueous methanol as the solvent. Testosterone was recrystallized after acetylation.

\section{Measurement of radioactivity and quantification of radio-} active steroids after TLC

Radioactivity was measured by liquid scintillation counting as described previously (Voogt et al., 1986). Radioactive areas on TLC plates were detected and recorded with a Berthold LB-2723 thin-layer radiogramscanner. Peak areas were measured with a digitizer 9864A (Hewlett Packard). Percental distribution of radioactivity was determined by expressing the area of each peak as a percentage of the total area of all peaks.

\section{Estimation of steroids}

Progesterone and testosterone levels were estimated in homogenates of pyloric caeca and gonads by previously validated RIA methods (Dieleman and Schoenmakers, 1979; Dieleman et al., 1983). The antiserum (S74 B7) for the RIA of progesterone, against $11 \alpha$-hydroxyprogesteronehemisuccinate BSA conjugates, was raised in sheep. The antiscrum (3R3TR3) against testosteron-3-oxo-oxime-BS $\Lambda$ conjugates was raised in rabbit.

Progesterone and testosterone were extracted from the homogenates with $n$-hexane $(99.5 \%$ : Merck AG, Darmstadt, FRG) and $n$-hexane-diethylether $(4: 1, v / v)$, respectively.

\section{Processing of data}

Conversion percentages of the radiolabelled precursors were calculated for 0.10 and $0.30 \mathrm{~g}$ of gonad tissue in experiments I and II, respectively, and for $0.50 \mathrm{~g}$ of pyloric caeca tissue in both experiments. The values refer to the whole period of incubation.

Results were tested by analysis of variance (Sokal and Rohlf, 1969), separately for males and females, and for gonads and pyloric caeca.

\section{RESULTS}

In experiment $I$, both the experimental and the control group consisted of six male and four female animals. In experiment II the control group consisted of five animals of each sex, whereas the experimental group consisted of five male and four female animals.

During experiment I the animals had not eaten at all, whereas in experiment II the sea stars of the control and experimental group had consumed 54 and 81 mussels, respectively.

All the incubations with pregnenolone showed a very low metabolism of this steroid. Even after 2 or $2.5 \mathrm{hr}$ of incubation only a little had been converted. The main products formed were progesterone and $17 \alpha$-hydroxypregnenolone, which were only tentatively identified by TLC. In experiment II some dehydroepiandrosterone had been formed in the ovaries, whereas no measurable conversion had occurred in the testes. Conversion percentages are given in Table 1.

There is a slight tendency of somewhat higher conversion percentages in the experimental groups. Statistical analysis revealed that only the production of $17 \alpha$-hydroxypregnenolone in pyloric caeca of female animals had significantly increased after zine exposure $(P=0.03)$

Scannograms of the incubations with dehydroepiandrosterone showed three peaks, of which one corresponded with the radioactive precursor used. The second one was identified by TLC and recrystallization to be androstenediol. The third peak corresponded with fatty-acyl androstenediol. The isolation and identification of this metabolite will be described elsewhere (Voogt et al., in preparation). In gonads, esterification was only modest, whereas in pyloric caeca it may be quite important (nearly half of the conversion products). Conversion percentages are shown in Table 2. From these data, the total amount of androstenediol produced was calculated by adding up the amounts of remained and esterified androstenediol. Further, the ratio was determined between esterified and total amount of androstenediol. In both experiments, exposure to cadmium resulted in an increased total production of androstenediol in the gonads of female starfish $(P=0.04)$.

$3 \beta$-Hydroxy-5 $\alpha$-pregnan-20-one, identified by TLC and recrystallization till constant specific radioactivity, was the main product formed in incubations with progesterone, while only trace amounts of $5 \alpha$-pregnane-3,20-dione were found. In all the incubations of cxpcriment II and in those of pyloric caeca of the male animals from experiment I, small amounts of $17 \alpha$-hydroxyprogesterone-tentatively

Table 1. The percentage conversion $( \pm \mathrm{SD})$ of ${ }^{3} \mathrm{H}$-pregnenolone into progesterone and $17 \alpha$-hydroxypregnenolone by pieces of tissue from gonads and pyloric caeca of sea stars exposed to cadmium or zinc

\begin{tabular}{|c|c|c|c|c|c|c|}
\hline & \multicolumn{3}{|c|}{$\begin{array}{l}\text { Conversion into } \\
\text { progesterone }\end{array}$} & \multicolumn{3}{|c|}{$\begin{array}{c}\text { Conversion into } \\
17 \alpha \text {-hydroxypregnenolone }\end{array}$} \\
\hline & Control & $\mathrm{Cd}^{2+}$ & $\mathrm{Zn}^{2+}$ & Control & $C d^{2}$ & $\mathrm{Zn}^{2+}$ \\
\hline \multicolumn{7}{|l|}{ Experiment I } \\
\hline ¿ Gonads & $1.4 \pm 0.7$ & $2.7 \pm 3.6$ & $1.4 \pm 1.3$ & - & - & - \\
\hline \& Pyloric caeca & \pm & \pm & - & $2,3 \pm 1.2$ & $2.5+1.2$ & $2.0 \pm 0.7$ \\
\hline Gonads & $2.2 \pm 1.7$ & $2.4 \pm 1.0$ & $2.2 \pm 1.1$ & $1.8 \pm 1.7$ & $<0.1$ & $<0.1$ \\
\hline Pyloric caeca & - & - & $=$ & $1.9 \pm 0.4$ & $1.9 \pm 0.8$ & $3.0 \pm 0.7^{*}$ \\
\hline \multicolumn{7}{|l|}{ Experiment II } \\
\hline 3 Gonads & $<0.1$ & $<0.1$ & & - & $\ldots$ & \\
\hline s Pyloric caeca & - & - & & $4.5 \pm 1.2$ & $5.5 \pm 1.4$ & \\
\hline Gonads & $2.4 \pm 0.9$ & $3.1 \pm 1.0$ & & $2.3 \pm 1.3$ & $3.9 \pm 4.1$ & \\
\hline 9 Pyloric caeca & $=$ & - & & $4.2 \pm 1.2$ & $5.1 \pm 2.5$ & \\
\hline
\end{tabular}

$* P<0.05$. 
Table 2. The percentage conversion $( \pm \mathrm{SD})$ of ${ }^{3} \mathrm{H}$-dehydroepiandrosterone into androstenediol and fatty-acyl androstenediol by pieces of tissue from gonads and pyloric caeca of sea stars exposed to cadmium or zinc

\begin{tabular}{|c|c|c|c|c|c|c|}
\hline & \multicolumn{3}{|c|}{$\begin{array}{l}\text { Conversion into } \\
\text { androstenediol }\end{array}$} & \multicolumn{3}{|c|}{$\begin{array}{c}\text { Conversion into } \\
\text { fatty-acyl androstenediol }\end{array}$} \\
\hline & Control & $\mathrm{Cd}^{2+}$ & $\mathrm{Zn}^{2+}$ & Control & $\mathrm{Cd}^{2+}$ & $\mathrm{Zn}^{2+}$ \\
\hline $\begin{array}{l}\text { Experiment } 1 \\
\delta \text { Gonads } \\
o \text { Pyloric caeca } \\
\text { o Gonads } \\
\text { o Pyloric caeca }\end{array}$ & $\begin{array}{l}21.9 \pm 8.2 \\
24.6 \pm 10.4 \\
10.0 \pm 6.4 \\
29.0 \pm 19.8\end{array}$ & $\begin{array}{l}22.7 \pm 14.0 \\
34.3 \pm 15.4 \\
20.4 \pm 5.5 \\
36.6 \pm 12.8\end{array}$ & $\begin{array}{l}20.0 \pm 13.0 \\
25.9 \pm 8.7 \\
20.8 \pm 18.9 \\
36.4 \pm 12.5\end{array}$ & $\begin{array}{c}20.2 \pm 19.8 \\
<0.1 \\
5.3 \pm 4.0\end{array}$ & $\begin{array}{c}- \\
15.9 \pm 12.4 \\
1.0 \pm 0.3 \\
15.3 \pm 8.1\end{array}$ & $\begin{array}{c}- \\
21.6 \pm 18.4 \\
1.0 \pm 0.7 \\
17.2 \pm 9.5\end{array}$ \\
\hline $\begin{array}{l}\text { Experiment II } \\
\delta \text { Gonads } \\
\delta \text { Pyloric caeca } \\
\text { t Gonads } \\
\text { o Pyloric caeca }\end{array}$ & $\begin{array}{r}6.8 \pm 1.6 \\
24.7 \pm 4.3 \\
4.8 \pm 2.4 \\
26.8 \pm 9.0\end{array}$ & $\begin{array}{r}9.0 \pm 3.5 \\
27.2 \pm 2.0 \\
11.5 \pm 6.6 \\
21.7 \pm 6.5\end{array}$ & & $\begin{array}{c}0.8 \pm 0.8 \\
13.2 \pm 9.9 \\
<0.1 \\
8.3 \pm 4.8\end{array}$ & $\begin{array}{c}3.1 \pm 5.2 \\
4.7 \pm 1.6 \\
1.3 \pm 0.5 \\
13.0 \pm 10.3\end{array}$ & \\
\hline
\end{tabular}

identified by TLC - were present. The conversion percentages are listed in Table 3 . Statistical analysis of these data revealed a significantly higher production of $3 \beta$-hydroxy-5 $\alpha$-pregnan-20-one and $17 \alpha$ hydroxyprogesterone in, respectively, the gonads and pyloric caeca of female animals from experiment II exposed to cadmium.

In the incubations with ${ }^{3} \mathrm{H}$-androstenedione three metabolites had been formed. The major product was testosterone, which was identified by TLC and recrystallization; the second important product was fatty-acyl testosterone, which was identified-after alkaline hydrolysis - in the same way. The third metabolite, $3 \beta$-hydroxy- $5 \alpha$-androstan-17-one, had been formed in small amounts and was identified tentatively by TLC. The intermediate $5 \alpha$-androstane3,17 -dione was present only in trace amounts. The conversion percentages are given in Table 4. Statistical analysis of these data showed that the production of testosterone in pyloric caeca from male animals exposed to cadmium is significantly higher than in those from the control animals $(P=0.002$ and 0.04 in experiments I and II, respectively).

In experiment III, pieces and a homogenate of the pyloric caeca of a male sea star were incubated with ${ }^{3} \mathrm{H}$-androstenedione in the presence or absence of cadmium. Testosterone and fatty-acyl testosterone were the main products formed, as they were in the former experiment (Table 4). Conversion percentages are given in Table 5. The total production of testosterone was calculated by adding up the values for remained and esterified testosterone. Further, the ratio fatty-acyl testosterone/total testosterone was determined (Table 5). Two-way analysis of variance

Table 3. The percentage conversion $( \pm \mathrm{SD})$ of ${ }^{3} \mathrm{H}$-progesterone into $3 \beta$-hydroxy-5 $\alpha$-pregnan-20-one and $17 \alpha$-hydroxyprogesterone by pieces of tissue from gonads and pyloric caeca of sea stars exposed to cadmium or zinc

\begin{tabular}{|c|c|c|c|c|c|c|}
\hline & \multicolumn{3}{|c|}{$\begin{array}{l}\text { Conversion into } \\
3 \beta \text {-hydroxy-5 } \alpha \text {-pregnan-20-one }\end{array}$} & \multicolumn{3}{|c|}{$\begin{array}{c}\text { Conversion into } \\
17 \alpha \text {-hydroxyprogesterone }\end{array}$} \\
\hline & Control & $\mathrm{Cd}^{2+}$ & $\mathrm{Zn}^{2+}$ & Control & $\mathrm{Cd}^{2+}$ & $\mathrm{Zn}^{21}$ \\
\hline $\begin{array}{l}\text { Experiment I } \\
\text { क Gonads } \\
\text { कै Pyloric caeca } \\
\text { o Gonads } \\
\text { क Pyloric caeca }\end{array}$ & $\begin{array}{c}8.6 \pm 5.5 \\
23.1 \pm 8.7 \\
5.4 \pm 2.3 \\
30.3 \pm 12.9\end{array}$ & $\begin{array}{r}15.5 \pm 12.6 \\
27.3 \pm 5.1 \\
6.0 \pm 2.8 \\
21.2 \pm 5.0\end{array}$ & $\begin{array}{r}9.9 \pm 4.7 \\
27.4 \pm 7.0 \\
16.2 \pm 9.6 \\
31.7 \pm 7.8\end{array}$ & $\begin{array}{c}<0.1 \\
1.0 \pm 1.2 \\
<0.1 \\
<0.1\end{array}$ & $\begin{array}{c}<0.1 \\
0.5 \pm 0.6 \\
<0.1 \\
<0.1\end{array}$ & $\begin{aligned} & <0.1 \\
0.7 & \pm 0.5 \\
& <0.1 \\
& <0.1\end{aligned}$ \\
\hline $\begin{array}{l}\text { Experiment II } \\
\text { o Gonads } \\
\text { o Pyloric caeca } \\
\text { क Gonads } \\
\text { o Pyloric caeca }\end{array}$ & $\begin{array}{c}52.5 \pm 11.3 \\
38.3 \pm 8.5 \\
9.0 \pm 3.2 \\
35.4 \pm 10.0\end{array}$ & $\begin{array}{l}45.0 \pm 9.1 \\
39.0 \pm 4.7 \\
33.3 \pm 19.6^{*} \\
42.6 \pm 9.9\end{array}$ & & $\begin{array}{l}1.7 \pm 0.6 \\
2.8 \pm 0.5 \\
0.9 \pm 0.9 \\
2.3 \pm 0.3\end{array}$ & $\begin{array}{l}1.9 \pm 0.2 \\
3.2 \pm 1.6 \\
2.1 \pm 2.8 \\
4.2 \pm 0.6^{* *}\end{array}$ & \\
\hline
\end{tabular}

$* P=0.028$

$* * P \ll 0.001$

Table 4. The percentage conversion ( $\pm \mathrm{SD}$ ) of ${ }^{3} \mathrm{H}$-androstenedione into testosterone, fatty-acyl testosterone and $3 \beta$-hydroxy-5x-androstane3,17-dione by pieces of tissue from gonads and pyloric caeca of sea stars exposed to cadmium or zinc

\begin{tabular}{|c|c|c|c|c|c|c|c|c|c|}
\hline & \multicolumn{3}{|c|}{$\begin{array}{l}\text { Conversion into } \\
\text { testosterone }\end{array}$} & \multicolumn{3}{|c|}{$\begin{array}{c}\text { Conversion into } \\
\text { fatty-acyl testosterone }\end{array}$} & \multicolumn{3}{|c|}{$\begin{array}{c}\text { Conversion into } \\
3 \beta \text {-hydroxy- } 5 \alpha \text {-androstane-3,17-dione }\end{array}$} \\
\hline & Control & $\mathrm{Cd}^{2+}$ & $\mathrm{Zn}^{2+}$ & Control & $\mathrm{Cd}^{2+}$ & $\mathrm{Zn}^{2+}$ & Control & $\mathrm{Cd}^{2+}$ & $\mathrm{Zn}^{2+}$ \\
\hline $\begin{array}{l}\text { Experiment I } \\
\text { o Gonads } \\
\text { के Pyloric caeca } \\
\text { Gonads } \\
\text { o Pyloric caeca }\end{array}$ & $\begin{array}{r}4.1 \pm 2.6 \\
25.8 \pm 5.6 \\
1.7 \pm 0.7 \\
26.4 \pm 13.5\end{array}$ & $\begin{array}{c}2.2 \pm 1.8 \\
39.5 \pm 5.4^{*} \\
2.8 \pm 1.3 \\
38.9 \pm 8.0\end{array}$ & $\begin{array}{r}3.1 \pm 0.7 \\
30.5 \pm 6.7 \\
2.1 \pm 0.9 \\
34.9 \pm 5.9\end{array}$ & $\begin{array}{c}7.4 \pm 5.6 \\
\overline{-} \\
9.6 \pm 11.1\end{array}$ & $\begin{array}{c}8.9 \pm 7.1 \\
\overline{-} \\
10.2 \pm 8.6\end{array}$ & $\begin{array}{c}7.2 \pm 6.7 \\
\overline{-} \\
10.1 \pm 6.9\end{array}$ & $\begin{array}{c}<0.1 \\
0.9 \pm 1.0 \\
<0.1 \\
2.7 \pm 1.4\end{array}$ & $\begin{array}{c}<0.1 \\
0.9 \pm 1.0 \\
1.0 \pm 0.7 \\
1.3 \pm 0.4\end{array}$ & $\begin{array}{c}<0.1 \\
0.6 \pm 0.9 \\
1.1 \pm 0.8 \\
1.5 \pm 0.5\end{array}$ \\
\hline 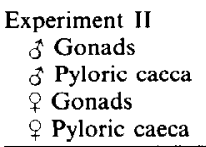 & $\begin{array}{r}7.4 \pm 5.3 \\
27.4 \pm 4.9 \\
1.7 \pm 0.4 \\
31.5 \pm 6.1\end{array}$ & $\begin{aligned} 9.6 & \pm 5.3 \\
35.2 & \pm 3.9^{*} \\
3.6 & \pm 1.6 \\
27.9 & \pm 6.4\end{aligned}$ & & $\begin{array}{c}4.7 \pm 2.0 \\
\overline{-} \\
9.4 \pm 6.5\end{array}$ & $\begin{array}{c}8.6 \pm 7.1 \\
4.0 \pm 1.6\end{array}$ & & $\begin{array}{l}4.4 \pm 2.9 \\
1.2 \pm 0.4 \\
1.4 \pm 0.7 \\
1.5 \pm 0.5\end{array}$ & $\begin{array}{l}2.4 \pm 1.0 \\
1.7 \pm 0.7 \\
1.4 \pm 0.6 \\
1.5 \pm 1.1\end{array}$ & \\
\hline
\end{tabular}


Table 5. The percentage of steroids $( \pm S D$ ) formed by pieces and a homogenate of the pyloric caeca of a male sea star, incubated with ${ }^{3} \mathrm{H}$-androstenedione in the presence or absence of cadmium. Also given are the ratios of fatty-acyl testosterones (FAT)/total amount of tetstosterone produced (TT), as well as the $F$-values of the two-way analysis of variance

\begin{tabular}{|c|c|c|c|c|}
\hline & Testosterone & $\begin{array}{c}\text { Fatty-acyl } \\
\text { testosterone }\end{array}$ & $\begin{array}{l}\text { Total amount } \\
\text { of testosterone } \\
\text { formed }\end{array}$ & FAT/TT \\
\hline \multicolumn{5}{|l|}{ Tissue } \\
\hline Control & $15.5 \pm 1.9$ & $7.7 \pm 3.9$ & $23.3 \pm 2.8$ & $0.32+0.13$ \\
\hline $\mathrm{Cd}^{2+}$ & $12.0 \pm 2.7$ & $11.5 \pm 4.3$ & $23.5 \pm 4.4$ & $0.48 \pm 0.13$ \\
\hline \multicolumn{5}{|l|}{ Homogenalt } \\
\hline Control & $24.9 \pm 5.1$ & $7.3 \pm 2.5$ & $32.2 \pm 4.7$ & $0.23 \pm 0.09$ \\
\hline $\mathrm{Cd}^{2+}$ & $21.4 \pm 6.9$ & $13.5 \pm 3.1$ & $35.0 \pm 4.8$ & $0.40 \pm 0.12$ \\
\hline Variance between tissue/homogenate & $19.40^{* * *}$ & 0.24 & $27.19 * * *$ & 2.73 \\
\hline Variance between control/ $\mathrm{Cd}^{2+}$ & 2.78 & $10.14^{* *}$ & 0.58 & $9.94^{* *}$ \\
\hline Interaction & 0.00 & 0.64 & 0.43 & 0.00 \\
\hline
\end{tabular}

$F|1,16| 0.05-4.49 ; F|1,16| 0.01=8.53 ; F|1,16| 0.001=16.1$

$* * P<0.01$.

$* * * P<0,001$

(Table 5) showed that testosterone production in homogenates is significantly higher than in pieces of intact tissue, but that testosterone esterification is not different in homogenates and tissue pieces. On the other hand, testosterone production is not affected by cadmium, whereas its esterification is strongly influenced.

Levels of progesterone and testosterone in gonads and pyloric caeca were estimated by means of radioimmunoassays. Gonadal tissue was not available for these assays in experiment $I$, due to the small size of these organs at that time of the year. The results are given in Table 6.

\section{DISCUSSION}

In the first experiment, pieces of pyloric caeca or gonad tissue from sea stars which had been exposed to cadmium or zinc were incubated with a number of steroids to study the effects of these metals on steroid metabolism. In later experiments zinc was left out because its effects were less pronounced than those of cadmium and the results showed a higher variance which made them less suitable for statistical analysis.

Metabolism of pregnenolone (Table 1) was very low in both experiments, although in the second cxperiment conversion into $17 \alpha$-hydroxypregnenolone was somewhat higher than in the first one. The metabolic pathway catalyzed by the enzyme $3 \beta$-hydroxysteroiddehydrogenase ( $3 \beta$-HSD), leading to the production of progesterone, seems to be followed exclusively in the gonads. On the other hand, $17 \alpha$-hydroxylasc activity, resulting into the production of $17 \alpha$-hydroxypregnenolone, seems to be more prominent in pyloric caeca, but is also present in ovaries.

Although the conversion percentages tend to be somewhat higher in the experimental groups, only the production of $17 \alpha$-hydroxypregnenolone in the pyloric caeca of female animals exposed to zinc was significantly different from that in the corresponding control groups.

Androstenediol and fatty-acyl androstenediol were the main metabolites formed in incubations with dehydroepiandrosterone (Table 2). Gonadal androstenediol formation was considerably higher in experiment I than in experiment II. This is even more obvious when it is taken into account that conversion percentages in the first experiment are based on $0.10 \mathrm{~g}$ and in the second experiment on $0.30 \mathrm{~g}$ of gonad tissue. Since this phenomenon is not observed in the pyloric caeca, it is probable that this difference in metabolic activity is related to the different reproductive stage of the gonads.

As in the experiment with pregnenolone, conversion percentages tend to be higher in the experimental groups than in the control groups. Statistically, only the total production of androstenediol in ovaries of sea stars exposed to cadmium was significantly higher than that in control animals in both experiments.

Conversion percentages for male animals exposed to zinc are of the same magnitude as the control values, whereas for female sea stars they are closer to the values for cadmium exposed animals. This suggests that the effects of zinc on steroid metabolism may be different in male and female animals.

Table 6. Mean ( $\pm S D$ ) progesterone and testosterone levels in groups of sea stars, Asterias rubens, exposed to cadmium or zinc, expressed as ng/g fresh weight

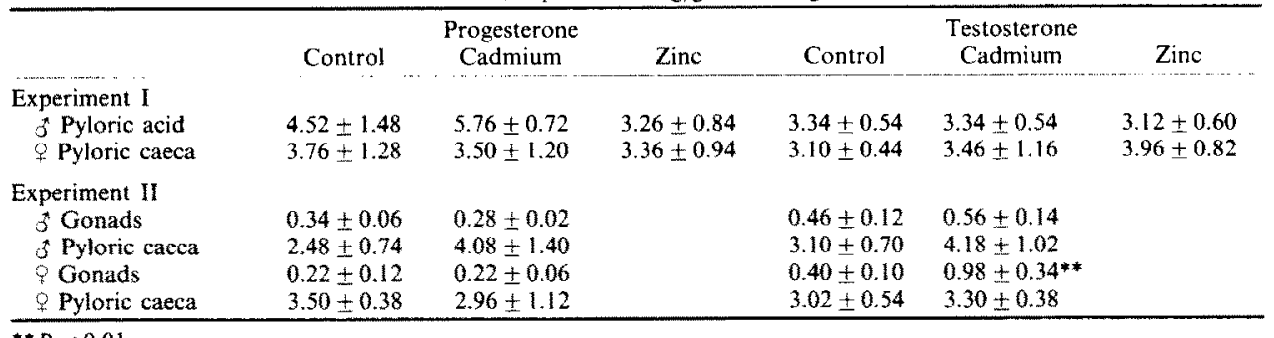

$* * P<0.01$ 
Esterification of androstenediol is an important route in dehydroepiandrosterone metabolism in pyloric caeca. The physiological significance of this process is as yet unknown. Exposure to cadmium seems to stimulate this esterification in female and to inhibit this process in male animals. Two-way analysis of variance (expI/expII-control/cadmium) showed that esterification in pyloric cacca of female animals exposed to cadmium is significantly higher than in those of control animals $(P<0.05$; results of two-way analysis of variance have not been indicated in the tables). Similar analyses showed the ratio of esterified and total amount of androstenediol in pyloric caeca of male animals to be lower and in those of female starfish to be higher $(P<0.05$ in both cases) after cadmium exposure. Two-way analysis of variance of the data of experiment II $(\mathrm{f} / \mathrm{\beta}$-control /cadmium) showed a significant interaction $(P<0.025)$, indicating that the effect of cadmium on this ratio is sex-dependent.

Conversion percentages of progesterone in animals exposed to cadmium or zinc were slightly higher than those in control animals (Table 3). In experiment I none of these differences were significant; not even the much higher mean yield of $3 \beta$-hydroxy-5 $\alpha$ prenan-20-one in the gonads of female animals exposed to zinc differed significantly from the corresponding value of the control animals. In experiment II, the differences mentioned above were statistically different in two cases. The increased activity of the enzyme $17 \alpha$-hydroxylase in the pyloric caeca of female animals exposed to cadmium is interesting since the activity of this enzyme had also increased in the incubations with pregnenolone in the same organs after exposure to zinc (Table 1).

Table 4 shows that the production of testosterone in the pyloric caeca of male sea stars exposed to cadmium is significantly higher than that in control animals. This increased activity of the enzyme $17 \beta$-HSD after exposure to cadmium was also observed in incubations with dehydroepiandrosterone (Table 2), but in this case differences were only significant in ovaries.

The tendency of increased conversion percentages of radioactive precursors in animals exposed to cadmium is observed in both experiments. The significantly increased production of testosterone was found in both experiments (Table 4); that of androstenediol in ovaries was proven by a two-way analysis of variance (Table 2). The production of $17 \alpha$-hydroxypregnenolonc (Table 1) was increased after exposure to zinc in experiment I. Since exposure to zinc was omitted in experiment II, it is unknown whether this effect could be reproduced. The foregoing shows that the results of experiment I are not different from those of experiment II. Since the animals from the former experiment had not eaten at all, we can conclude that the main way of entrance of cadmium (and zinc) into sea stars is via the surrounding medium and not via the food consumed.

In order to obtain a first indication about the effects of the changes in steroid metabolism observed in animals exposed to heavy metals on steroid levels, the titers of progesterone and testosterone were estimated in the gonads and pyloric caeca of these animals (Table 6). Exposure to cadmium caused a significant increase in the testosterone levels in ovaries $(P=0.008)$, which cannot be explained directly from an increased testosterone production in these organs, no more than the increased production of testosterone in pyloric caeca of male animals is reflected in a higher level of this steroid.

Two-way analysis of variance of the testosterone levels in pyloric caeca of zinc exposed and control animals gave a significant value $(P<0.05)$ for the interaction, indicating that the effect of zinc on the testosterone level in pyloric caeca is sex-dependent. The same way of analysis showed a highly significant increase $(P<0.005)$ of the progesterone level in pyloric caeca of cadmium exposed male sea stars, which again is not counterparted by significant changes in progesterone metabolism in these organs.

In conclusion, the exact relation between steroid metabolism and steroid titers is as yet unclear. However, it may be indicative that significant changes in both parameters always dealt with increased values. Since the relation mentioned above is unknown, as is the exact function of steroids in sea star reproduction, it is impossible to make statements (other than speculations) about the nature and the magnitude of the effects of exposure to heavy metals on reproduction of sea star. Yet, it is very likely that the reproduction will be affected

Our insight into the regulatory function of steroids in reproduction is very limited in general, but this holds particularly with respect to testosterone. Actually, this is the very first time that testosterone levels have been estimated in sea star and as yet we do not even know whether and how these levels change during the reproductive cycle. The present levels estimated are in the same order as those of progesterone; further, they are much higher in the pyloric caeca than in the gonads, and there are no obvious differences among the sexes.

The changes is steroid metabolism and titers described in the foregoing section have all been observed in animals which had been exposed to cadmium (or zinc) for 21 days. Therefore, no conclusions can be drawn as to the mechanism(s) underlying the changes in metabolic activity. So one could imagine a direct effect of cadmium on metabolism due to its interaction with the enzyme under study or to its involvement as a cofactor in the enzyme-catalyzed reaction; but also an indirect effect of cadmium resulting from its interaction with the synthesis of enzymes (at the level of transcription or translation) may be possible. In the first case, cadmium changes the conditions of the enzymatic reaction concerned directly and in a qualitative way, and its effect will be evident instantaneously. In the second case, metabolism is influenced indirectly by changing the number of copies of the enzyme involved, and the effect will (initially) increase with exposure time.

To obtain some insight into the mechanism underlying the metabolic changes induced by cadmium, we studied in experiment III the metabolism of androstenedione in pyloric caeca of male sea star, because metabolic activity had been influenced significantly by cadmium in experiments I and II (Table 4). Pieces and homogenates of pyloric caeca tissue were incubated for $20 \mathrm{~min}$. Table 6 shows that testosterone production in homogenates is 
significantly higher than in pieces of intact tissue, but that testosterone esterification is not different in homogenates and tissue pieces. This indicates that, probably, the diffusion of androstenedione into the intact tissue is the limiting factor in testosterone production (Voogt et al., 1986). Once testosterone has been formed, its esterification is not different in homogenates and in tissue. This table also shows that the esterification of testosterone is strongly affected by cadmium, which, due to the design of this experiment, must be a direct effect of cadmium on the enzymatic reaction. The production of testosterone is not affected by cadmium, whereas in experiment 1 and II (Table 4) it had significantly increased. This makes it likely that the effect of cadmium on testosterone production is an indirect one. Of course it can be objected that this has not been definitively proven. Obviously, it is impossible to combine the design of the experiments I and II with that of III in the same animals. So there is only the evidence of the reproducibility of the effect in the experiments I and II,

The question after the mechanisms underlying the effect of cadmium on steroid metabolism is interesting, but more important is the question after the consequences of cadmium exposure for the reproduction of sea stars and therefore for the stability of sea star populations. Much research has still to be done to answer this question.

Acknowledgements-The authors thank Dr S. J. Dieleman for his participation in the estimation of steroid levels and Miss Miriam van Hattum and Miss Marjan van Dijk for typing the manuscript.

\section{REFERENCES}

Biswas N. M., Chanda S., Ghosh A. and Chakraborty J. (1976) Fffect of cadminm on spermatogenesis in toad (Bufo melanostictus). Endokrinologie 68, 349-352.

Chiquoine A. D. (1964) Observations on the early events of cadmium necrosis of the testes. Anat. Rec. 149, 23-36.

Dieleman S. J. and Schoenmakers H. J. N. (1979) Radioimmunoassays to determine the presence of progesterone and estrone in the starfish Asterias rubens. Gen. comp. Endocr. 39, 534-542.
Dieleman S. J., Kruip Th. A. M., Fontijne P., de Jong W. H. R. and Van der Weyden G. C. (1983) Changes in oestradiol, progesterone and testosterone concentrations in follicular fluid and in the micromorphology of preovulatory bovine follicles relative to the peak of luteinizing hormone. $J$. Endocr. 97, 31-42.

Ghosh P. K., Ghosh A. H. and Biswas N. M. (1984) Effect of cadmium chloride on steroidogenic enzymes in the Bidder's organ of the toad (Bufo melanostictus). Experientia 40, $91-92$.

Jangoux M. and Vloebergh M. (1973) Contribution à l'étude du cycle annuel de reproduction d'une population d'Asterias rubens (Echinodermata, Asteroidea) du littoral belge. Neth. J. Sea Res. 6, 389-408.

Mackawa R., Suzuki T. and Tsunenari Y. (1964) Damage of the gonads induced by cadmium in male and female ring doves (Streptopelia risoria). Acta anat. mippon. 39, 294-301.

Needleman H. L. (1980) In Lead Toxicity (Edited by Singhal R. L. and Thomas J. A.), pp. 1-17. Urban \& Schwarzenberg, Baltimore-Munich.

Parizek J. and Zahor Z. (1956) Effect of cadmium salt on testicular tissue. Nature, New Biol. 177, 1036.

Sarkar A. K. and Mondal R. (1973) Injurious effect of cadmium on testis of domestic pigeon and its prevention by zinc. Indian $J$, exp. Biol, 11, 108-109.

Sokal R. R. and Rohlf F. J. (1969) Biometry: The Principles and Practice of Statistics in Biological Research. Freeman, San Francisco.

Voogt P. A. and Van Rheenen J. W. A. (1986) Androstenedione metabolism in the sea star Asterias rubens L. studied in homogenates and intact tissue: Biosynthesis of the novel steroid fatty-acyl testosterone. Comp. Biochem. Physiol. 85B, 497-501.

Voogt P. A., Oudejans R. C. H. M. and Broertjes J. J. S. (1984) Steroids and reproduction in starfish. Adv. invert. Reprod. 3, 151-161.

Voogt P. A., Van Rheenen J. W. A., Lambert J. G. D., De Groot B. T. and Mollema C. (1986) Effects of different experimental conditions on progesterone metabolism in the sea star Asterias rubens. Comp. Biochem. Physial. 84B, $397-402$.

Wiebe I. P., Salhanick A. I. and Myers K. I. (1983) On the mechanism of action of lead in the testis: in vitro suppression of FSH receptors, cyclic AMP and steroidogenesis. Life Sci. 32, 1997-2005.

Wright R. S. (1971) A reagent for the non-destructive location of steroids and some other lipophilic materials on silicagel thin-layer chromatograms. J. Chromat. 59, $220-221$. 